\title{
Successful Treatment of Chronic Lymphocytic Leukemia Multifocal Central Nervous System Involvement with Ibrutinib
}

\author{
Kronik Lenfositik Löseminin Multifokal Santral Sinir Sistemi Tutulumunun Ibrutinib ile \\ Başarılı Tedavisi
}

\author{
(D) Anna Christoforidou1, (D) Georgios Kapsas², (D) Zoe Bezirgiannidou¹, (D) Spyros Papamichos 1 , (D) loannis Kotsianidis ${ }^{1}$ \\ ${ }_{1}^{1}$ Democritus University of Thrace, Department of Hematology, Alexandroupolis, Greece \\ 2Democritus University of Thrace, Department of Radiology, Alexandroupolis, Greece
}

To the Editor,

Central nervous system involvement (CNSi) is rare in the course of chronic lymphocytic leukemia (CLL). The frequency ranges from $0.8 \%$ to $1 \%$ [1], and it is often underreported. Diagnosis is challenging and there is no consensus on the optimal therapy or survival. CNSi manifests as either leptomeningeal infiltration or a focal parenchymal lesion, or both [1]. We describe the case of a CLL patient who progressed with parenchymal CNS involvement and was successfully treated with ibrutinib.

A 71-year-old woman was followed without treatment at the hematology clinic for 12 years for asymptomatic CLL, Binet stage I, exhibiting slowly progressive lymphocytosis and mild hepatosplenomegaly. In March 2016 she presented with expressive aphasia, memory problems, confusion, and headache, but no B symptoms. Neurological examination confirmed the mental and speech impairment but was otherwise unremarkable. Thoracic and abdominal computed tomography scan showed no lymphadenopathy or progression of visceromegaly. Her complete blood count was unchanged compared to the previous year with WBC lymphocytes at $14,652 \times 10^{\circ} / \mathrm{L}$, Htc at $45 \%$, and platelets at $144 \times 10^{9} / \mathrm{L}$, with typical CLL morphology and immunophenotype (CD19 83\% with CD5+/CD23+/CD20+low/CD38-/slglow) and unmutated p53. IGH mutational analysis showed a mutated clone with IGHV3-7/IGHD1-26/IGHJ4 rearrangement. Serum chemistry was normal apart from elevated lactate dehydrogenase at $303 \mathrm{U} / \mathrm{L}$ (upper normal limit: $248 \mathrm{U} / \mathrm{L}$ ). Antinuclear antibody and rheumatoid factor were negative; C-reactive protein, C3, and C4 levels were within the normal limits. Magnetic resonance imaging (MRI) showed a contrast-enhanced irregularly shaped mass of $22 \times 17 \times 16 \mathrm{~mm}$ in the left frontal lobe with intense edema and midline shift (Figure 1A). Lumbar puncture showed $5 / \mu \mathrm{L}$ nucleated cell count, $5 / \mu \mathrm{L}$ erythrocytes, $0.4 \mathrm{~g} / \mathrm{L}$ protein, and no monoclonal B lymphocytes (CD5/CD19) by flow cytometry. Extensive investigations for infection with cytomegalovirus, Epstein-Barr virus, human immunodeficiency virus, herpes simplex virus, ortoxoplasma antibodies as well as PCR for Cytomegalovirus DNA were negative in both serum and cerebrospinal fluid. She was referred to a neurosurgeon but the

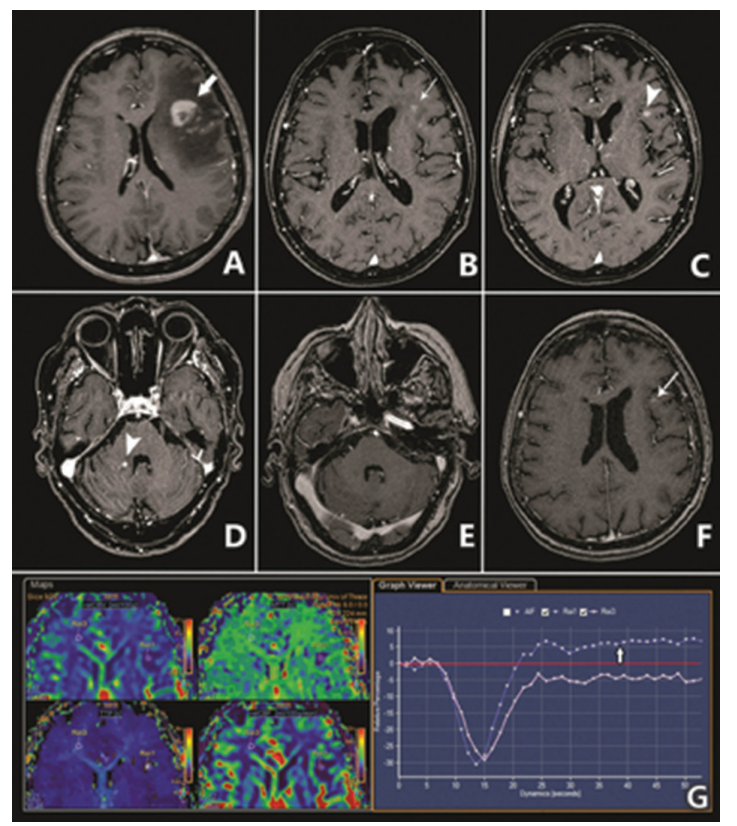

Figure 1. A) Initial presentation of the enhancing lesion in the left frontal lobe (thick arrow), with considerable perilesional edema. B, C, D) After one and four rituximab plus a high-dose methylprednisolone cycles there was a reduction of the enhancing lesion (thin arrow) and edema; however, new enhancing lesions appeared in the left frontal operculum and the right middle cerebellar peduncle (arrowheads). E) Brain magnetic resonance imaging 5 months after ibrutinib therapy demonstrates complete resolution of the cerebellar lesion and F) minimal enhancement in the area of the lesion in the left frontal operculum (arrow). G) Dynamic susceptibility contrast perfusion imaging. Comparison between the enhancing lesion and the normal contralateral side demonstrates an overshooting of the intensity curve of the lesion above the baseline (arrow). This phenomenon is suggestive of lymphoma [149×172 mm (72×72 DPI)].

patient was reluctant to undergo a core biopsy of the brain lesion. However, dynamic susceptibility contrast MRI perfusion imaging displayed a signal intensity curve overshooting above the baseline that was suggestive of lymphoma (Figure 1G) [2].

Considering the above findings, the patient was treated in an exploratory fashion with rituximab plus a high-dose 
methylprednisolone (RHDM) regimen (rituximab at $500 \mathrm{mg} / \mathrm{m}^{2}$ i.v. and methylprednisolone at $1 \mathrm{~g}$ iv for 4 days). After 2 monthly cycles, the neurological symptoms partially regressed, but her MRI findings deteriorated with a new lesion on the left frontal lobe, although the original lesion was impressively smaller (Figures 1B and 1C). Continued RHDM resulted in a decrease of lymphocytosis to $10.9 \times 10^{9} / \mathrm{L}$, but repeat MRI showed an atypical pattern of older lesions receding coupled with the appearance of new ones in multiple cerebral sites (Figure 1D). Since we did not have proof of whether the infiltrating neoplastic cells were identical to the original leukemic clone or a manifestation of Richter's syndrome (RS), second-line treatment was a challenge. The patient was switched to ibrutinibat $420 \mathrm{mg}$ per day, based on the recent reports of ibrutinib's CNS penetration and effectiveness, even in high-grade lymphomas. Three months later there was a partial improvement in the MRI findings and no new lesions. Currently on the $15^{\text {th }}$ month of ibrutinib therapy, she is completely symptom-free, shows partial response of CLL and stable neuroimaging improvement, 21 months after initial CNS involvement (Figure 1E, 1F).

Autopsy studies have found leukemic meningitis and parenchymal brain involvement in up to $20 \%$ of CLL patients, but clinical syndromes are very rarely reported [3], with the first ever case published by Solal-Celigny et al. [4]. CNSi is diagnosed by neuroimaging, cerebrospinal fluid evaluation, and core tissue biopsy that differentiate between CLL, Richter's transformation, or another solid tumor. Strati et al. [1] reviewed 33 patients with CLL CNSi and, among them, 11 out of 12 patients with CNS RS had later developed systematic disease [1]. Our patient did not at any point develop systematic Richter's syndrome and has an excellent clinical course during the 21 months of follow up which is suggestive of a CLL rather than RS origin of the CNSi.

The treatment outcome of clinically apparent CNSi is unclear, as most studies are retrospective. The management ranges from CLL therapy alone [5] to CNS irradiation, intrathecal chemotherapy, and intensive CNS-lymphoma modalities. Intrathecal rituximab has been used in several case reports and in a small study for high-grade CNS Iymphomas but never in CLL [6]. In a recent study the median overall survivalof patients with CLL or RS brain involvement was 12 and 11 months, respectively [1]. On the contrary, a cohort of 30 French patients had much better overall survivalof $65 \%$ at 5 years [7]. Ibrutinib is an oral Bruton tyrosine kinase inhibitor approved for B-CLL [8]. It is a small molecule that crosses the blood-brain barrier with promising results in CNS Iymphoma, as shown in some cases of mantle cell Iymphoma $[9,10,11]$, in Waldenström macroglobulinemia patients $[12,13,14]$, and, more importantly, in a phase I study of 20 patients with relapsed/refractory CNS lymphoma showing 75\% overall response rate, including 8 complete responses, although responses were relatively short-lived [15]. Ibrutinib has a convenient outpatient oral administration scheme with minimal toxicity and is an attractive option for CNS lymphoma

\begin{tabular}{|c|c|c|c|c|c|c|c|c|}
\hline & Patient 1 [16] & $\begin{array}{l}\text { Patient } 2 \\
{[16]}\end{array}$ & $\begin{array}{l}\text { Patient } 3 \\
\text { [16] }\end{array}$ & Patient 4 [16] & $\begin{array}{l}\text { Patient } \\
5[7]\end{array}$ & $\begin{array}{l}\text { Patient } 6 \\
\text { [7] }\end{array}$ & $\begin{array}{l}\text { Patient } 7 \\
\text { [17] }\end{array}$ & $\begin{array}{l}\text { Patient } 8 \\
\text { (present } \\
\text { case) }\end{array}$ \\
\hline $\begin{array}{l}\text { Time since CLL } \\
\text { diagnosis }\end{array}$ & $\begin{array}{l}\text { Median of } 106 \\
\text { months* }\end{array}$ & $\begin{array}{l}\text { Median of } \\
106 \text { months }^{*}\end{array}$ & $\begin{array}{l}\text { Median } \\
\text { of } 106 \\
\text { months }\end{array}$ & $\begin{array}{l}\text { Median of } 106 \\
\text { months* }\end{array}$ & $N / A^{*}$ & $N / A^{*}$ & $N / A^{*}$ & 12 years \\
\hline $\begin{array}{l}\text { Binet stage at } \\
\text { CNSi }\end{array}$ & C & B & C & A & N/A & $\mathrm{N} / \mathrm{A}$ & C & A \\
\hline $\begin{array}{l}\text { CLL progression at } \\
\text { CNSi diagnosis }\end{array}$ & Yes & No & Yes & No & $\mathrm{N} / \mathrm{A}$ & $\mathrm{N} / \mathrm{A}$ & $\mathrm{N} / \mathrm{A}$ & No \\
\hline CNSi presentation & 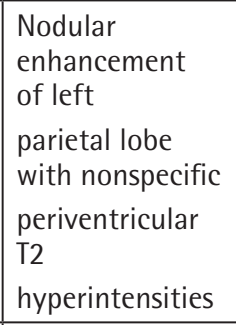 & $\begin{array}{l}\text { Leukemic } \\
\text { meningitis }\end{array}$ & $\begin{array}{l}\text { Leukemic } \\
\text { meningitis }\end{array}$ & $\begin{array}{l}\text { Thickening of } \\
\text { optic nerves and } \\
\text { chiasma; FLAIR } \\
\text { hyperintensities } \\
\text { with nodular } \\
\text { lesion of internal } \\
\text { occipitotemporal } \\
\text { region } \\
\end{array}$ & $\mathrm{N} / \mathrm{A}$ & $\mathrm{N} / \mathrm{A}$ & $\begin{array}{l}\text { Cervical } \\
\text { myelopathy } \\
\text { with } \\
\text { expansion of } \\
\text { the spinal } \\
\text { cord from C2 } \\
\text { to C7 }\end{array}$ & $\begin{array}{l}\text { Multifocal } \\
\text { parenchymal } \\
\text { masses, with } \\
\text { biggest one } \\
\text { at } 22 \times 1 \times 16 \\
\mathrm{~mm} \text { in the } \\
\text { left frontal } \\
\text { lobe }\end{array}$ \\
\hline Del17p & Yes & Yes & No & Yes & $N / A$ & $\mathrm{~N} / \mathrm{A}$ & $\mathrm{N} / \mathrm{A}$ & No \\
\hline $\begin{array}{l}\text { CNS response to } \\
\text { ibrutinib }\end{array}$ & $\begin{array}{l}\mathrm{MRI} \\
\text { normalization }\end{array}$ & $\mathrm{CR}$ & CR & $\begin{array}{l}\text { MRI near } \\
\text { normalization }\end{array}$ & N/A & $\mathrm{N} / \mathrm{A}$ & $\begin{array}{l}\text { MRI } \\
\text { normalization }\end{array}$ & $\begin{array}{l}\text { MRI near } \\
\text { normalization }\end{array}$ \\
\hline $\begin{array}{l}\text { Duration of } \\
\text { response to } \\
\text { ibrutinib (months) }\end{array}$ & 9 & 14 & 8 & 9 & N/A & $\mathrm{N} / \mathrm{A}$ & 18 & 15 \\
\hline
\end{tabular}


compared to traditional intensive chemotherapy and/or intrathecal therapy.

So far, there are seven published cases of CLL with CNSi treated with ibrutinib monotherapy (Table 1): two with nodular masses $[7,16]$, four with leptomeningeal disease $[7,16]$, and one with cervical myelopathy [17]. None of these patients underwent brain biopsy. All patients received the standard dose of 420 $\mathrm{mg} /$ day and all of them responded with sustained complete responseor partial response, with a median follow-up of 8 to 18 months. Our patient had multiple brain masses and shows an ongoing response to second line ibrutinib monotherapy for a total of 21 months as per December 2017, when the latest brain MRI was performed.

In conclusion, this case further supports the efficacy of ibrutinib in CLL with CNSi, suggesting a potential future change in the frontline management and also the outcome of this rare condition.

Keywords: Chronic lymphocytic leukemia, Central nervous system, CNS, Ibrutinib

Anahtar Sözcükler: Kronik lenfositik lösemi, Santral sinir sistemi, SSS, İbrutinib

Conflict of Interest: The authors of this paper have no conflicts of interest, including specific financial interests, relationships, and/or affiliations relevant to the subject matter or materials included.

\section{References}

1. Strati $P$, Uhm JH, Kaufmann TJ, Nabhan C, Parikh SA, Hanson CA, Chaffee KG, Call TG, Shanafelt TD. Prevalence and characteristics of central nervous system involvement by chronic lymphocytic leukemia. Haematologica 2016;101:458-465.

2. Mangla R, Kolar B, Zhu T, Zhong J, Almast J, Ekholm S. Percentage signal recovery derived from MR dynamic susceptibility contrast imaging is useful to differentiate common enhancing malignant lesions of the brain. AJNR Am J Neuroradiol 2011;32:1004-1010.

3. Barcos M, Lane W, Gomez GA, Han T, Freeman A, Preisler H, Henderson E. An autopsy study of 1206 acute and chronic leukemias (1958 to 1982). Cancer 1987;60:827-837.

4. Solal-Celigny P, Schuller E, Courouble Y, Gislon J, Elghozi D, Boivin P. Cerebromeningeal location of chronic lymphoid leukemia. Rapid immunochemical diagnosis and complete remission by intrathecal chemotherapy. Presse Med 1983;12:2323-2325.

5. Benjamini $\mathrm{O}_{\text {, Jain }} \mathrm{P}$, Schlette E, Sciffman JS, Estrov Z, Keating M. Chronic lymphocytic leukemia with central nervous system involvement: a high-risk disease? Clin Lymphoma Myeloma Leuk 2013;13:338-341.

6. Rubenstein JL, Fridlyand J, Abrey L, Shen A, Karch J, Wang E, Issa S, Damon L, Prados M, McDermott M, O'Brien J, Haqq C, Shuman M. Phase I study of intraventricular administration of rituximab in patients with recurrent CNS and intraocular lymphoma. J Clin Oncol 2007;25:1350-1356.

7. Wanquet $A$, Birsen $R$, Bonnet $C$, Boubaya $M$, Choquet $S$, Dupuis J, Lepretre S, Re D, Fahri J, Michallet AS, Ysebaert L, Lemal R, Lamy T, Delarue R, Troussard X, Cymbalista F, Levy V, Dietrich PY, Leblond V, Aurran-Schleinitz T. Management of central nervous system involvement in chronic lymphocytic leukaemia: a retrospective cohort of 30 patients. Br J Haematol 2017;176:37-49.

8. Byrd JC, Furman RR, Coutre SE, Flinn IW, Burger JA, Blum KA, Grant B, Sharman JP, Coleman $M$, Wierda WG, Jones JA, Zhao W, Heerema NA, Johnson AJ, Sukbuntherng J, Chang BY, Clow F, Hedrick E, Buggy JJ, James DF, O'Brien S. Targeting BTK with ibrutinib in relapsed chronic lymphocytic leukemia. N Engl J Med 2013;369:32-42.

9. Tucker DL, Naylor G, Kruger A, Hamilton MS, Follows G, Rule SA. Ibrutinib is a safe and effective therapy for systemic mantle cell lymphoma with central nervous system involvement - a multi-centre case series from the United Kingdom. Br J Haematol 2017;178:327-329.

10. Bernard S, Goldwirt L, Amorim S, Brice P, Briere J, de Kerviler E, Mourah S, Sauvageon $\mathrm{H}$, Thieblemont C. Activity of ibrutinib in mantle cell lymphoma patients with central nervous system relapse. Blood 2015;126:1695-1698.

11. Gonzalez-Bonet LG, Garcia-Boyero R, Gaona-Morales J. Mantle cell lymphoma with central nervous system involvement simulating bilateral subdural hematomas. World Neurosurg 2017;99:808.

12. Cabannes-Hamy A, Lemal R, Goldwirt L, Poulain $S$, Amorim $S$, Perignon $R$ Berger J, Brice P, De Kerviler E, Bay JO, Sauvageon H, Beldjord K, Mourah S, Tournilhac 0 , Thieblemont C. Efficacy of ibrutinib in the treatment of BingNeel syndrome. Am J Hematol 2016;91:17-19.

13. Castillo JJ, D'Sa S, Lunn MP, Minnema MC, Tedeschi A, Lansigan F, Palomba $M L$, Varettoni M, Garcia-Sanz R, Nayak L, Lee EQ, Rinne ML, Norden AD, Ghobrial IM, Treon SP. Central nervous system involvement by Waldenström macroglobulinaemia (Bing-Neel syndrome): a multi-institutional retrospective study. Br J Haematol 2016;172:709-715.

14. Mason C, Savona S, Rini JN, Castillo JJ, Xu L, Hunter ZR, Treon SP, Allen SL. Ibrutinib penetrates the blood brain barrier and shows efficacy in the therapy of Bing Neel syndrome. Br J Haematol 2017;179:339-341.

15. Grommes C, Pastore A, Gavrilovic I, Kaley T, Nolan C, Omuro AM, Wolfe J, Pentsova E, Hatzoglou V, Mellinghoff I, DeAngelis L. Single-agent ibrutinib in recurrent/refractory central nervous system lymphoma. Blood 2016;128:783.

16. Wanquet $A$, Birsen $R$, Lemal $R$, Hunault $M$, Leblond $V$, Aurran-Schleinitz T. Ibrutinib responsive central nervous system involvement in chronic lymphocytic leukemia. Blood 2016;127:2356-2358.

17. Tam CS, Kimber T, Seymour JF. Ibrutinib monotherapy as effective treatment of central nervous system involvement by chronic lymphocytic leukaemia. Br J Haematol 2017;176:829-831.
Address for Correspondence/Yazışma Adresi: Anna CHRISTOFORIDOU, M.D., Democritus University of Thrace, Department of Hematology, Alexandroupolis, Greece Phone : +302551351511

E-mail : annachristof@yahoo.gr ORCID-ID: orcid.org/0000-0002-3979-8318
Received/Geliş tarihi: August 20, 2017

Accepted/Kabul tarihi: January 26, 2017

DOI: $10.4274 /$ tjh.2017.0313 